\title{
Supreme Court ruling receives warm welcome
}

\begin{abstract}
Washington. The US Supreme Court has clarified the rules on the use of scientific evidence, making judges responsible for ensuring that "any and all scientific testimony or evidence admitted is not only relevant, but reliable."
\end{abstract}

The ruling is expected to improve the quality of scientific evidence heard throughout the federal judiciary, where unsound science and competing scientific claims have presented persistent problems.

Last week's ruling arises from the Supreme Court's adjudication on the admissibility of evidence in a damage suit brought against Merrell Dow Pharmaceuticals on behalf of two San Diego children born with shortened or missing limbs to women who took the now-discontinued drug Bendectin to ward off morning-sickness during pregnancy. The case began in 1984.

During the trial of Daubert v. Merrell, lawyers for the families wished to present evidence from pathologists and epidemiologists that would have supported the plaintiffs' case, but were denied by two Californian courts on the grounds that the evidence had not been peer-reviewed, published or generally accepted in the scientific community.

That is the essence of the 70-year-old legal standard called the "Frye test", which allows as evidence only that based on scientific methods recognized as reliable. Rejecting that standard, the Supreme Court says the test should be whether the methods used to reach conclusions are sound.

That means that US judges must now sift reliable from ill-founded science by considering whether the claim is testable, whether it has been empirically tested and whether the testing has been carried out according to a scientific methodology.

\section{Europe's research plan still up in air}

Luxembourg. The European Community (EC) multi-billion dollar fourth framework programme for research (1994-98) seems to be heading for the delays that plagued its predecessor. The twelve research ministers meeting in Luxembourg last week failed to agree on what the total budget should be and how it should be divided.

The European Commission's own plan recommended a ECU13.1 billion budget, of which most ( 83.4 per cent) would be allocated to a research and development programme broken down into seven categories: information and communication technology (29.8 per cent); industrial technology (13.7 per cent); transport research (2.1 per cent); life sciences (10.1 per cent); environment ( 7.4 per cent); energy (19.3 per cent); and socioeconomics (1.0 per cent).

The commission would have divided the rest of the money between the three other activities of the framework programme: international cooperation, including that with eastern Europe ( 6 per cent); dissemination and optimization of results (4.6 per cent) and human capital and mobility ( 6 per cent).

No government demands major shifts in this allocation, but small demands can force stasis when they are in contradictory directions. Denmark, which held the rotating EC presidency until 1 July, put forward a compromise designed to bridge the various differences, but it did not succeed.

Thus Britain, France, Germany and the Netherlands, all of which have strong telecommunications industries which stand to benefit from future contracts, held out for more spending on information technology. Germany alone stood out for a much higher allocation to environmental research (12.3 per cent, compared with the Danish compromise of 8-10 per cent). Britain and France want lower spending on the life sciences, Belgium more on energy.

Many countries also want to see a reduced share for international cooperation and dissemination of results. Most countries are not yet ready to commit themselves on the total sum to be allocated to research from the what the EC call their internal policy budget, which also covers training and networking. The commission proposes that research should take about 60 per cent of this (ECU13.1 billion), but many want to reserve judgement until the EC's general budget as a whole is clearer.

Optimists still hope that disagreements can be ironed out in time, for approval at the next council of ministers meeting in December. Pessimists remember the political delays that held up approval of the third framework (1990-94). The impending ratification of the Maastricht Treaty may cause further delay. The treaty requires 'codecision', or the agreement on all significant issues of all three EC governing bodies - commission, parliament and council of ministers.

Codecision, while democratic, will probably lengthen all EC procedures. And elections due next June are likely to disrupt the smooth functioning of the Parliament, which could delay approval further if the framework programme falls seriously behind schedule.
"The ruling is wonderfully simple. If a theory fails to meet any of these three questions, it doesn't qualify as science and, therefore, doesn't make it into the courtroom," said Steven Gallagher of the Carnegie Commission on Science, Technology, and Government, which recently published a set of guidelines to help judges distinguish between good and bad science.

Including the Carnegie Commission, no fewer than 22 organizations and individuals offered the court a range of opinions on what kind of evidence should be allowed in courts. Among opinions supporting Merrell Dow were those of the American Medical Association, the National Academy of Sciences and the American Association for the Advancement of Science, all of which applaud last week's ruling.

The decision follows a period during which US courts have been criticized for reaching decisions at odds with scientific reality. The controversy peaked last year in the case of a claim that a spermicide had caused birth defects. The court had held that "sufficient evidence of causation", and not science, should influence the law.

Bert Black, who chairs the American Bar Association's Standing Committee on Scientific Evidence, believes the ruling will create "a real binding distinction between quack experts with crackpot theories and true scientists with sound reliable evidence."

Last week's decision seemed to satisfy both sides. The plaintiffs will not be barred from presenting their evidence, but that will be heard only if the courts agree that the science is sound.

Others are pleased by the ruling. US businesses, which have complained that the threat of unreliable testimony by "hired guns" has led to unwarranted jury awards in personal injury and malpractice lawsuits, are among them. But last week's ruling is also claimed as a victory by the groups of lawyers, science historians and epidemiologists who supported the plaintiffs.

Quick to point out that Galileo was persecuted for advocating heliocentrism, they say the decision will force courts to be more flexible with scientific mavericks whose work has not been accepted by peerreviewed journals. Given that much of the information relevant to legal cases is new to science, the ruling will also make it easier for litigants to put before juries evidence based on novel or experimental techniques. The new development will also affect the use made by courts of evidence from DNA fingerprinting, about which there has been controversy in recent years.

The ruling technically applies only to federal courts, but is expected to be followed by state courts as well. The practical difficulties have yet to emerge. Certainly it will make more work for the already-overburdened courts. Experts say judges will have to schedule even more preliminary hearings and hire experts to assist them in deciding what evidence to allow.

Susan Greene 